OPEN ACCESS

Edited by:

Zhong Jin,

Nanjing University, China

Reviewed by:

Mahmut Özacar

Sakarya University, Turkey Hongije Zhang,

Changchun University of Science and Technology, China

*Correspondence:

Purnendu Parhi

pparhi@ ravenshawuniversity.ac.in

Specialty section:

This article was submitted to

Inorganic Chemistry,

a section of the journal

Frontiers in Chemistry

Received: 22 February 2019

Accepted: 20 May 2019

Published: 06 June 2019

Citation:

Soren S, Hota I, Debnath AK,

Aswal DK, Varadwaj KSK and Parhi P (2019) Oxygen Reduction Reaction

Activity of Microwave Mediated

Solvothermal Synthesized

$\mathrm{CeO}_{2} / \mathrm{g}-\mathrm{C}_{3} \mathrm{~N}_{4}$ Nanocomposite.

Front. Chem. 7:403.

doi: 10.3389/fchem.2019.00403

\section{Oxygen Reduction Reaction Activity of Microwave Mediated Solvothermal Synthesized $\mathrm{CeO}_{2} / \mathbf{g}-\mathrm{C}_{3} \mathrm{~N}_{4}$ Nanocomposite}

\author{
Siba Soren ${ }^{1}$, Ipsha Hota ${ }^{1}$, A. K. Debnath ${ }^{2}$, D. K. Aswal ${ }^{2}$, K. S. K. Varadwaj ${ }^{1}$ and \\ Purnendu Parhi ${ }^{\text {* }}$ \\ ${ }^{1}$ Department of Chemistry, Ravenshaw University, Cuttack, India, ${ }^{2}$ Technical Physics Division, Bhabha Atomic Research \\ Center, Mumbai, India
}

Electrocatalytic active species like transition metal oxides have been widely combined with carbon-based nanomaterials for enhanced Oxygen Reduction Reaction (ORR) studies because of the synergistic effect arising between different components. The aim of the present study is to synthesize $\mathrm{CeO}_{2} / \mathrm{g}-\mathrm{C}_{3} \mathrm{~N}_{4}$ system and compare the ORR activity with bare $\mathrm{CeO}_{2}$. Ceria $\left(\mathrm{CeO}_{2}\right)$ embedded on $\mathrm{g}^{-} \mathrm{C}_{3} \mathrm{~N}_{4}$ nanocomposite was synthesized by a single-step microwave-mediated solvothermal method. This cerium oxide-based nanocomposite displays enhanced ORR activity and electrochemical stability as compared to bare ceria.

Keywords: $\mathrm{g}-\mathrm{C}_{3} \mathrm{~N}_{4}, \mathrm{CeO}_{2}$, cyclic voltammogram, linear sweep voltammetry, rotating disk electrode, rotating ring disk electrode

\section{INTRODUCTION}

Metal-air batteries and fuel cells are alternative energy transfer devices designed to meet the requirements of sustainable energy (Sun et al., 2017). Direct Methanol Fuel Cells (DMFCs) are documented as an ideal candidate for laptop, mobile, and digital camera applications. Efficient reduction of $\mathrm{O}_{2}$ to water is a major challenge in energy conversion in DMFCs. The Oxygen Reduction Reaction (ORR) in alkaline DMFCs proceeds via a 4-electron pathway, $\left(\mathrm{O}_{2}+2 \mathrm{H}_{2} \mathrm{O}\right.$ $\left.+4 \mathrm{e}^{-} \rightarrow 4 \mathrm{OH}^{-}\right)$which is preferable over the 2-electron pathway $\left(\mathrm{O}_{2}+\mathrm{H}_{2} \mathrm{O}+2 \mathrm{e}^{-} \rightarrow \mathrm{HO}_{2}^{-}+\right.$ $\mathrm{OH}^{-}$) (Zhang and Song, 2008). The 2-electron process is unfavorabl because of the production of corrosive peroxide species, which can cause degradation of electrochemical cells. The precious metal catalysts such as Pt and Pt- based alloys used to catalyze the ORR process are expensive and available in limited quantity (Peng and Yang, 2009; Kim et al., 2010). These Pt-based catalysts are also intolerant to methanol, which is used as fuel in DMFCs. Design of new non-precious electrocatalyst with improved ORR activity is still a challenge before the scientific community. First row transition metal oxides (TMOs) (Bashyam and Zelenay, 2006; Cheng et al., 2009; Jaouen et al., 2011; Cheng and Chen, 2012) have already been used as robust alternatives for promoting the ORR in alkaline conditions. The low electrical conductivity of the TMOs influences the electron transfer process in ORR (Soren et al., 2016).

Carbon materials possess a specific place for the ORR in DMFCs. Various carbon materials like graphite (Jiao et al., 2014), carbon black, carbon nanotube, and activated carbon are mostly used as supporting materials in the preparation of electrocatalysts due to their high electrical conductivity, corrosion resistance, porous structure and specific surface area (Liang et al., 2011). TMOs when 
embedded with reduced graphene oxide show enhanced catalytic performance because of a synergetic effect between TMOs and graphene oxide (Liang et al., 2011, 2012; Wang et al., 2011; Guo and Sun, 2012; Guo et al., 2012; Wu et al., 2015).

Hetero atoms (e.g., N, B, P, S, and I) were also doped in the reduced graphene oxide in order to improve the catalytic active sites in reduced graphene oxide (Behnam, 2017). In the recent past, nitrogen-doped graphene oxide has become a potential carbon-based electrocatalyst for ORR because of its low cost, high stability, and high efficiency (Qu et al., 2010; Geng et al., 2011; Yang et al., 2012; Paraknowitsch and Thomas, 2013). The electronic environment of doping nitrogen on a reduced graphene sheet in three configurations (e.g., pyridynic, pyrrolic, and graphitic nitrogen) induces an uneven charge distribution in adjacent sites, and as a result it alters the local spin or charge density. It promotes oxygen adsorption and helps in the enhancement of ORR performance (Ikeda et al., 2008; Niwa et al., 2009; Liu et al., 2010; Qu et al., 2010; Rao et al., 2010; Kim et al., 2011; Li et al., 2011, 2013; Sheng et al., 2011; Zhang and Xia, 2011; Lai et al., 2012; Parvez et al., 2012; Sharifi et al., 2012; Wang et al., 2012; Zhang et al., 2013; Zheng et al., 2013; Bag et al., 2014). Transition metal oxide embedded in $\mathrm{N}$ doped carbon systems is reported as a promoter of ORR catalytic activity by facilitating electron transfer (Bag et al., 2014). Rare earth oxide-based systems are now extensively studied for ORR due to their unique electronic structure, bonding characteristics and variable oxidation states. There are very few reports available in the literature where rare earth oxides such as lanthanum oxide, samarium oxide, and cerium oxide have been studied for their ORR properties (Soren et al., 2016; Wang et al., $2016,2017)$. The unique structural properties of $\mathrm{CeO}_{2}$ have contributed toward the promising electrocatalytic activity of $\mathrm{CeO}_{2}$. However, poor electronic conductivity of $\mathrm{CeO}_{2}$ limits its application toward ORR. Thus, in order to enhance the electrocatalytic activity, $\mathrm{CeO}_{2}$ is doped with different metals or embedded with a conductive active framework. Recently, our group has published an article on ORR activity of the $\mathrm{CeO}_{2} / \mathrm{NrGO}$ system (Soren et al., 2016).

Researchers have found a new material analogy to $\mathrm{N}$ doped rGO called graphitic carbon nitride $\left(\mathrm{g}-\mathrm{C}_{3} \mathrm{~N}_{4}\right.$ ) (Qiao et al., 2016). It is a carbon- and nitrogen-based polymeric material. Graphitic carbon nitride $\left(\mathrm{g}-\mathrm{C}_{3} \mathrm{~N}_{4}\right)$ is a nitrogenrich carbon-based material. But as reported in the literature g- $\mathrm{C}_{3} \mathrm{~N}_{4}$ is an inert electrocatalyst (Liu and Zhang, 2013; Zou et al., 2013). However, g- $\mathrm{C}_{3} \mathrm{~N}_{4}$ with metal doping or metal oxide doping has already been reported as a promising electrocatalyst for ORR and OER (Oxygen Evolution Reaction), when embedded with transition metal/metal oxide (Liu and Zhang, 2013; Zou et al., 2013).

It is expected that $\mathrm{CeO}_{2} / g-\mathrm{C}_{3} \mathrm{~N}_{4}$ composite can enhance the ORR in fuel cells. In this paper, we have investigated the ORR activity of $\mathrm{CeO}_{2}$ embedded with g$\mathrm{C}_{3} \mathrm{~N}_{4}$ to show whether it follows a 2-electron or 4-electron pathway in the ORR process. The hybrid $\mathrm{CeO}_{2} / g-\mathrm{C}_{3} \mathrm{~N}_{4}$ nanostructures were prepared by the microwave mediated polyol method.

\section{MATERIALS AND METHODS}

\section{Chemicals}

Melamine, Ammonium Cerium (IV) Nitrate and 1, 4-Butanediol were procured from HIMEDIA. All the chemicals were used as received.

\section{Synthesis of $\mathbf{g}-\mathrm{C}_{3} \mathrm{~N}_{4}$}

About $3 \mathrm{~g}$ of melamine was taken in china crucible and was heated for $4 \mathrm{~h}$ at $520^{\circ} \mathrm{C}$ with a moderate heating rate of $10^{\circ} \mathrm{C} / \mathrm{min}$ inside the muffle furnace. The product obtained was cooled to room temperature. The prepared $\mathrm{g}_{-} \mathrm{C}_{3} \mathrm{~N}_{4}$ was characterized for further work.

\section{Synthesis of $\mathrm{CeO}_{2} / \mathrm{g}-\mathrm{C}_{3} \mathrm{~N}_{4}$ Composite}

In typical synthesis $50 \mathrm{mg}$ of the above-prepared $\mathrm{g}-\mathrm{C}_{3} \mathrm{~N}_{4}$ was added to $20 \mathrm{ml}$ of 1,4-butanediol. The solution was stirred at $300 \mathrm{rpm}$ in a $50 \mathrm{ml}$ beaker to make a heterogeneous mixture. A total of $250 \mathrm{mg}$ of ammonium cerium (IV) nitrate was added to this heterogeneous solution and again stirred at the same rpm for $10 \mathrm{~min}$ until the color of the solution changed from light yellow to orange red. The entire solution was transferred to a Teflon vessel. The vessel was tightly sealed and irradiated with microwave radiation (MDS 6) for $10 \mathrm{~min}$ at $180^{\circ} \mathrm{C}$. The reaction mixture was allowed to cool to room temperature after completion of the reaction. The obtained light yellow-colored precipitate was centrifuged several times with distilled water, ethanol, and acetone to remove the impurities. Finally, the product was kept for drying in an oven over night at $60^{\circ} \mathrm{C}$.

\section{Characterization}

The crystallographic phases were identified by XRD measurements using a Rigaku Ultima-IV Advance X-ray Diffractometer operating at $40 \mathrm{KV}$ (radiation source $\mathrm{Cu} \mathrm{K \alpha}$, wavelength $=1.5418 \AA$ ). FTIR analysis was carried out with the help of Thermo Fischer Nicolet iS5 FTIR instrument. The XPS measurement was performed using DESA-150 electron analyzer (Staib $(1253.6 \mathrm{eV})$ as radiation source. Transmission Electron Microscope (TEM) and High Resolution Transmission Electron Microscope (HRTEM) images were obtained by the Model FEI Technai G2 S-Twin (Benson et al., 2014). Electrochemical Impedance Spectroscopic analysis was recorded $\mathrm{CH} 660 \mathrm{E}$ electrochemical work station.

\section{Electrochemical Measurements}

The electrochemical measurements were conducted in a conventional three-electrode system using a Metrohm Autolab 204 B.V. (Metrohm Autolab, Netherland). During the measurements, saturated $\mathrm{Ag} / \mathrm{AgCl}$ electrode, $\mathrm{Pt}$ wire, and modified glassy carbon (GC) electrode were used as reference, counter, and working electrode respectively. Synthesized electrocatalyst material was loaded on a pre-cleaned GC electrode during preparation of the working electrode. For the preparation of catalytic ink $5 \mathrm{mg}$ of as synthesized electrocatalyst was dispersed in $2 \mathrm{ml}$ isopropanol, $3 \mathrm{ml}$ double distilled $\mathrm{H}_{2} \mathrm{O}$, and 25 micro liter Nafion solution (as binder) in an ultrasonic bath for $30 \mathrm{~min}$ (Soren et al., 2016). About $12 \mu \mathrm{l}$ of well-dispersed catalytic ink ( $\sim 0.012 \mathrm{mg})$ was drop casted onto the polished GC 

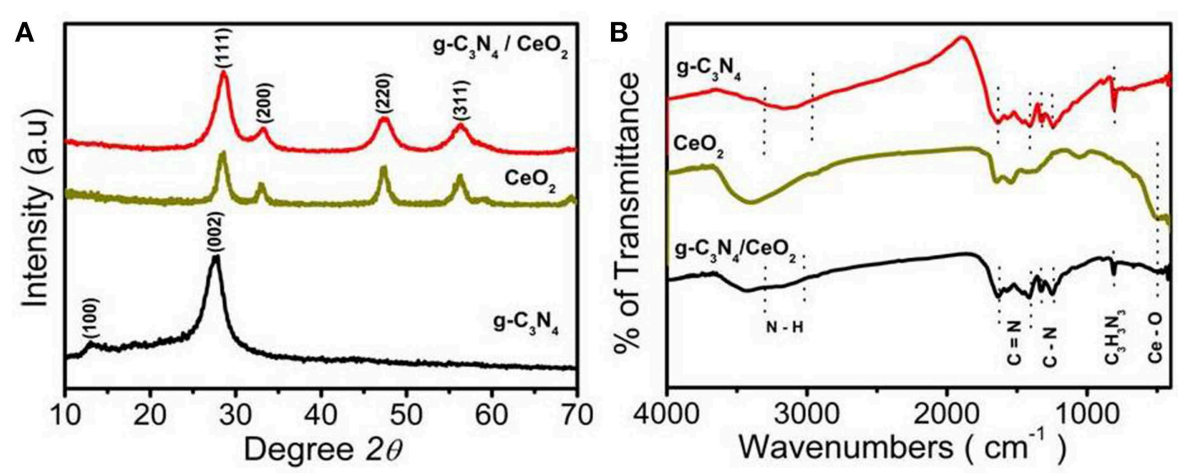

FIGURE 1 | (A) XRD of $\mathrm{g}-\mathrm{C}_{3} \mathrm{~N}_{4}, \mathrm{CeO}_{2}, \mathrm{CeO}_{2} / \mathrm{g}-\mathrm{C}_{3} \mathrm{~N}_{4}$ and (B) FTIR spectra of $\mathrm{g}-\mathrm{C}_{3} \mathrm{~N}_{4}, \mathrm{CeO}_{2}, \mathrm{CeO}_{2} / \mathrm{g}-\mathrm{C}_{3} \mathrm{~N}_{4}$.
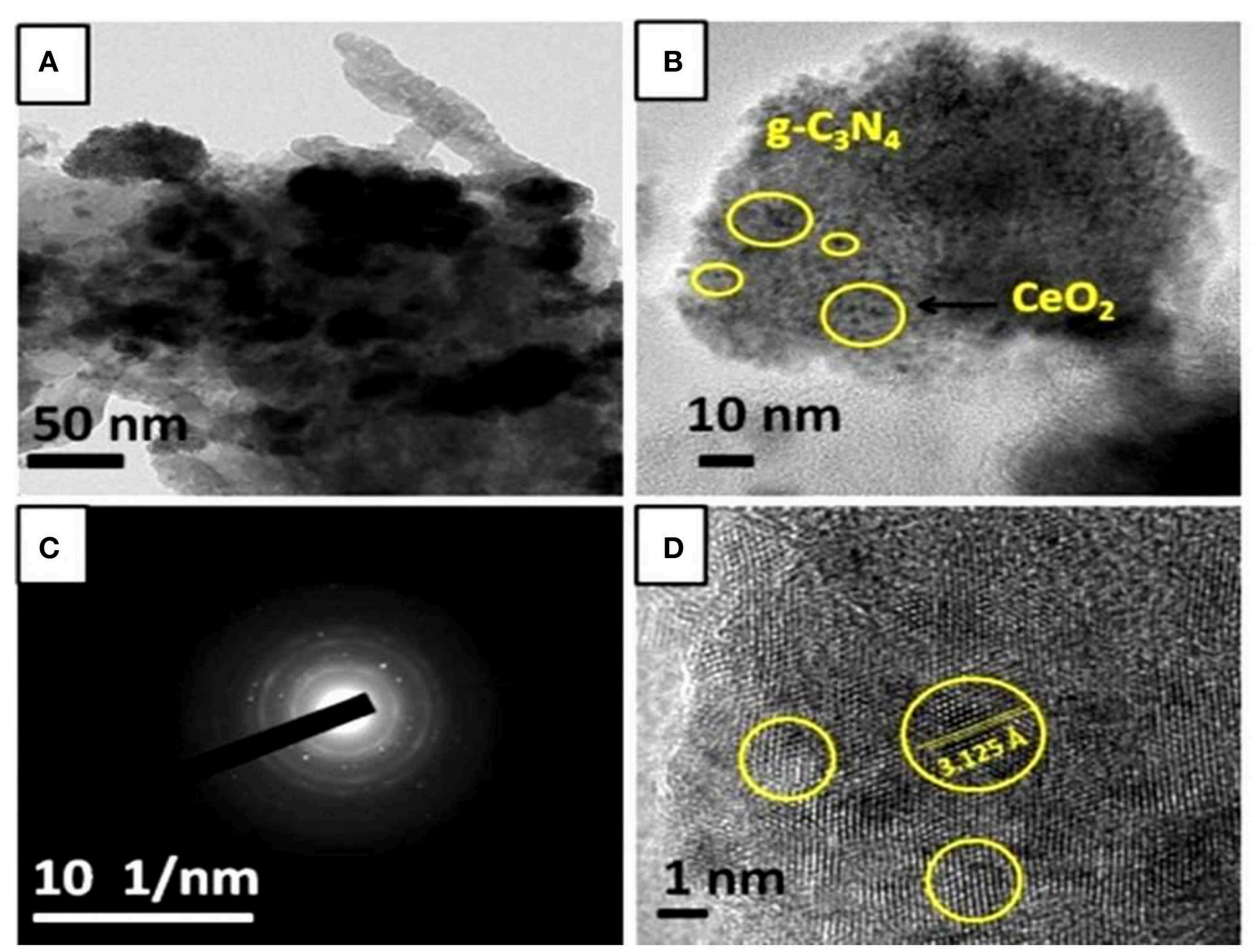

FIGURE 2 | (a) TEM, (b) HRTEM at $10 \mathrm{~nm}$, (c) SAED, and (d) HRTEM at $1 \mathrm{~nm}$ of $\mathrm{CeO}_{2} / \mathrm{g}-\mathrm{C}_{3} \mathrm{~N}_{4}$.

electrode of surface area $\left(0.07067 \mathrm{~cm}^{2}\right)$. The modified glassy carbon electrode was dried in a vacuum oven for $3 \mathrm{~h}$. About 33.3 $\mu l$ of previously prepared catalyst ink was drop casted on RRDE electrode (GC disk electrode) with $5 \mathrm{~mm}$ diameter $(\mathrm{S}=0.196$ $\mathrm{cm}^{2}$ ) to make the loading the same as in RDE studies.

\section{RESULT AND DISCUSSION}

\section{Composition and Structure}

Characterization of $\mathrm{CeO}_{2} / \mathrm{gC}_{3} \mathrm{~N}_{4}$ Hybrid

$\mathrm{XRD}$ patterns of the synthesized composite (1:1) were studied and compared with the XRD pattern of individual $\mathrm{CeO}_{2}$ and g$\mathrm{C}_{3} \mathrm{~N}_{4}$ (Ferrero et al., 2016). In the case of a pure $\mathrm{g}-\mathrm{C}_{3} \mathrm{~N}_{4}$ sample, a strong diffraction peak appears at $27.61^{\circ}$ that corresponds to the (002) plane. The strong diffraction peak arises because of the stacking of the conjugated aromatic system (Wang et al., 2009). The sharp peak at $27.61^{\circ}$ indicates tight packing in $\mathrm{g}-\mathrm{C}_{3} \mathrm{~N}_{4}$, which is because of the strong binding between the layers and large localization of electrons. Another small peak at $13.12^{\circ}$ can be assigned to the (100) plane. The diffraction peaks of the pure cubic fluorite structure of $\mathrm{CeO}_{2}$ were indexed to the (111), (200), (220), and (311) planes (JCPDS 81-0792) (Soren et al., 2015). After the incorporation of $\mathrm{CeO}_{2}$ into the $\mathrm{g}^{-} \mathrm{C}_{3} \mathrm{~N}_{4}$ network, the $\mathrm{XRD}$ pattern shows an absence of peak at $13.12^{\circ}$ even though the weight ratio of $\mathrm{g}-\mathrm{C}_{3} \mathrm{~N}_{4}$ and $\mathrm{CeO}_{2}$ are nearly $1: 1$ in the composite (Liu and Zhang, 2013). The peak corresponding to the (111) plane of $\mathrm{CeO}_{2}$, which coincides with the highest intensity peak of 

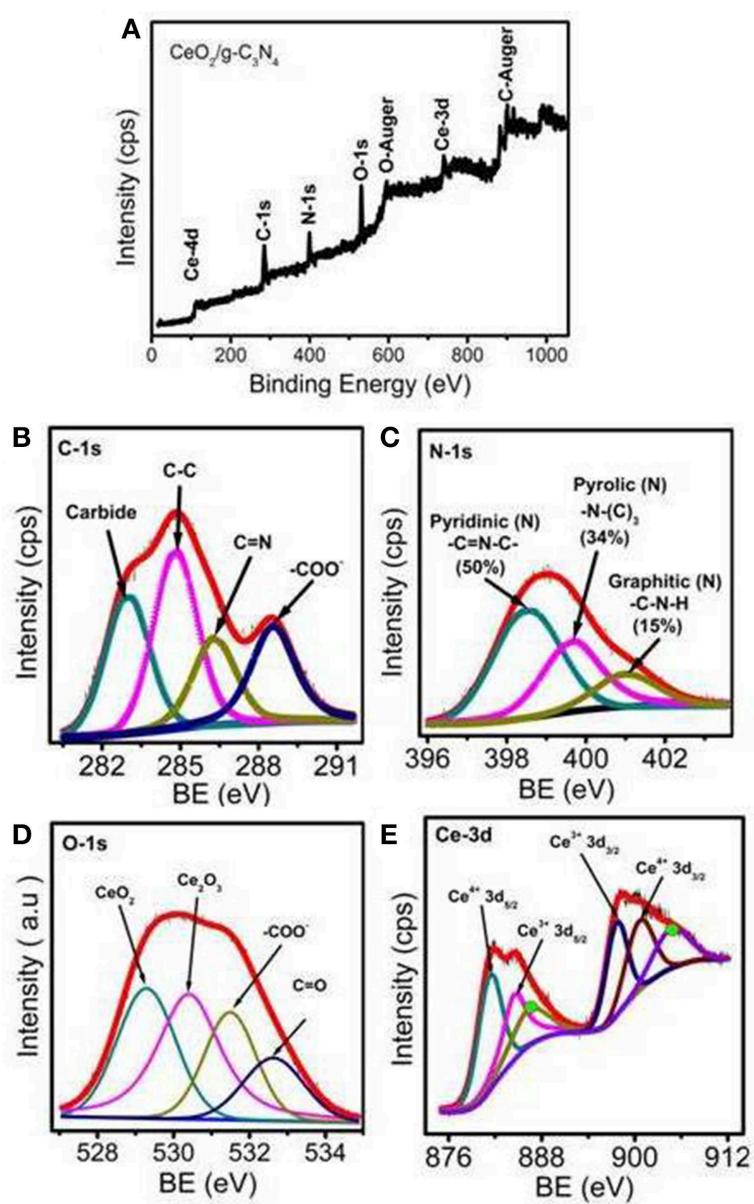

FIGURE 3 | (A) XPS survey scan of $\mathrm{CeO}_{2} / \mathrm{g}-\mathrm{C}_{3} \mathrm{~N}_{4}$, Deconvoluted XPS spectrum of (B) C 1s, (C) N 1s, (D) O 1s, (E) Ce 3d.

bare $\mathrm{g}-\mathrm{C}_{3} \mathrm{~N}_{4}$, has been shifted to higher $2 \theta$ value, and the intensity of the peak has also been increased. From these findings it can be concluded that $\mathrm{CeO}_{2}$ nanoparticles are successfully embedded into in-planes of g- $\mathrm{C}_{3} \mathrm{~N}_{4}$ sheets (Thomas et al., 2008; Zhang et al., 2008; Xu et al., 2013) (Figure 1A).

The chemical structures of the samples were evaluated by the FTIR analysis. A broad band between 3,000 and 3,500 $\mathrm{cm}^{-1}$ was noticed in the composite, which can be attributed to stretching vibration of $\mathrm{N}-\mathrm{H}$ and surface adsorbed water molecules. The absorption peaks at 1,572 and $1,632 \mathrm{~cm}^{-1}$ (Li et al., 2015) were due to $\mathrm{C}=\mathrm{N}$ stretching (Bojdys et al., 2008; Yan et al., 2009) while for aromatic C-N stretching, peaks at $1,253,1,320$, and $1,425 \mathrm{~cm}^{-1}$ were observed. The main structural peaks at $808 \mathrm{~cm}^{-1}$ corresponded to the breathing mode of triazine units of $\mathrm{g}-\mathrm{C}_{3} \mathrm{~N}_{4}$ (Xu et al., 2013), which reveals that the graphitic C-N network of $\mathrm{g}-\mathrm{C}_{3} \mathrm{~N}_{4}$ was not affect even after the inclusion of $\mathrm{CeO}_{2}$ in the $\mathrm{g}-\mathrm{C}_{3} \mathrm{~N}_{4}$ layer (Figure 1B).

$\mathrm{CeO}_{2} / g-\mathrm{C}_{3} \mathrm{~N}_{4}$ composite showed a layered structure of $\mathrm{g}^{-} \mathrm{C}_{3} \mathrm{~N}_{4}$ (Figure 2a), and several small dark images of $\mathrm{CeO}_{2}$ nanoparticle appeared in the TEM image
(Figure 2b). The appearance of some bright spots and the diffuse rings in the SAED pattern of $\mathrm{CeO}_{2} / g-\mathrm{C}_{3} \mathrm{~N}_{4}$ corresponds to the growth of crystalline $\mathrm{CeO}_{2}$ nanoparticle on the amorphous $\mathrm{g}-\mathrm{C}_{3} \mathrm{~N}_{4}$ sheet (Figure 2c). The fringe spacing was measureed to be $3.125 \AA$, which corresponds to the (111) lattice plane of the cubic fluorite $\mathrm{CeO}_{2}$ structure (Figure 2d).

The composition and chemical structure of the synthesized material were established by X-ray photoelectron spectroscopy. The high resolution XPS survey spectra of $\mathrm{C} 1 \mathrm{~s}, \mathrm{~N} 1 \mathrm{~s}, \mathrm{O} 1 \mathrm{~s}$, and $\mathrm{Ce} 3 \mathrm{~d}$ XPS spectra of $\mathrm{CeO}_{2} / \mathrm{g}-\mathrm{C}_{3} \mathrm{~N}_{4}$ (1:1) composite is shown in Figure 3A. The XPS spectra of the $\mathrm{C} 1 \mathrm{~s}$ core level for $\mathrm{CeO}_{2} / \mathrm{g}-\mathrm{C}_{3} \mathrm{~N}_{4}$ can be deconvoluted into four components including the standard reference carbon $(283 \mathrm{eV}$ ) (Xing et al., 2014). The peak at $284.8 \mathrm{eV}$ corresponds to $\mathrm{sp}^{2}$-bonded CC (Raymundo-Pinero et al., 2002). The peaks at 286.3 and $288.5 \mathrm{eV}$ (Guan et al., 2018) are ascribed to $\mathrm{C}=\mathrm{N}$ and $\mathrm{N}-$ $\mathrm{C}-\mathrm{N}$ in $\mathrm{g}-\mathrm{C}_{3} \mathrm{~N}_{4}$ respectively (Figure 3B) (Yan et al., 2012). The main peak of $\mathrm{N} 1 \mathrm{~s}$ at $398.5 \mathrm{eV}$ is assigned to $\mathrm{sp}^{2}$ nitrogen $(\mathrm{C}=\mathrm{N}-\mathrm{C})$ (pyridinic) present in triazine rings, while the peak at $399.6 \mathrm{eV}$ arises from the tertiary nitrogen bonded to carbon atoms in the form of $\mathrm{N}-(\mathrm{C})_{3}$ (pyrollic). The peak at $401.1 \mathrm{eV}$ can be ascribed to $\mathrm{g}(\mathrm{C}-\mathrm{N}-\mathrm{H})$ (ghaphitic) (Figure 3C) (Raymundo-Pinero et al., 2002). The \% of $\mathrm{N}$ in total spectrum is calculated to be $7.09 \%$. The percentages of different levels of nitrogen in the system were 50.6, 34.48, and $15.05 \%$ for pyridinic, pyrrolic, and graphitic nitrogen, respectively. The $\mathrm{O}$ $1 \mathrm{~s}$ spectrum is deconvoluted at $529.2,531.0$, and $533.2 \mathrm{eV}$ for $\mathrm{CeO}_{2}, \mathrm{COOH}$ and $\mathrm{OH}$ respectively. These spectrums suggest the formation of $\mathrm{CeO}_{2}$ on $\mathrm{g}-\mathrm{C}_{3} \mathrm{~N}_{4}$ (Figure 3D). The oxidation states of $\mathrm{Ce}$ in $\mathrm{g}-\mathrm{C}_{3} \mathrm{~N}_{4} / \mathrm{CeO}_{2}$ composites were examined by deconvolution of $\mathrm{Ce} 3 \mathrm{~d}$ peaks. The two peaks at 881.6 and $884.7 \mathrm{eV}$ can be attributed to $3 \mathrm{~d}_{5 / 2}$ of $\mathrm{Ce}^{4+}$ and $\mathrm{Ce}^{3+}$ core electrons respectively. Further peaks at 897.5 and $900.1 \mathrm{eV}$ can be ascribed to $3 \mathrm{~d}_{3 / 2}$ of $\mathrm{Ce}^{3+}$ and $\mathrm{Ce}^{4+}$, respectively (Figure $3 \mathrm{E}$ ) (Zheng et al., 2017).

\section{Electrochemical Performance of $\mathrm{CeO}_{2} / \mathrm{gC}_{3} \mathrm{~N}_{4}$ Hybrid}

The cyclic voltammogram $(\mathrm{CV})$ was performed in $\mathrm{N}_{2}$ as well as $\mathrm{O}_{2}$ saturated $0.1 \mathrm{M} \mathrm{KOH}$ solution for the three materials ( $\mathrm{g}$ $\mathrm{C}_{3} \mathrm{~N}_{4}, \mathrm{CeO}_{2}$ and $\mathrm{CeO}_{2} / \mathrm{g}-\mathrm{C}_{3} \mathrm{~N}_{4}$ ) in the potential range of -0.8 to $0.2 \mathrm{~V}$ at various scan rates (Ferrero et al., 2016). No reduction peaks were observed in the $\mathrm{N}_{2}$-saturated condition. After $\mathrm{O}_{2}$ was introduced for $30 \mathrm{~min}$, intense reduction peaks of $\mathrm{g}-\mathrm{C}_{3} \mathrm{~N}_{4}$ (Jiao et al., 2014), $\mathrm{CeO}_{2}$, and $\mathrm{CeO}_{2} / g-\mathrm{C}_{3} \mathrm{~N}_{4}$ at $\mathrm{E}_{\text {onset }}-0.3,-0.24$, and $-0.17 \mathrm{~V}$ vs. $\mathrm{Ag} / \mathrm{AgCl}$, respectively, were recorded (Figure 4A). To investigate ORR performance, linear sweep voltammetry (LSV) was recorded for the prepared materials together with commercial $20 \mathrm{wt} \% \mathrm{Pt} / \mathrm{C}$, in $\mathrm{O}_{2}$ saturated $0.1 \mathrm{M} \mathrm{KOH}$ solution using Rotating Disk Electrode (RDE) at 1,600 RPM (Wu X. et al., 2017). From the LSV, plot the onset potential was observed to be $-0.3,-0.23$, and $-0.2 \mathrm{~V}$ vs. $\mathrm{Ag} / \mathrm{AgCl}$ for $\mathrm{g}-\mathrm{C}_{3} \mathrm{~N}_{4}, \mathrm{CeO}_{2}$, and $\mathrm{CeO}_{2} / g-\mathrm{C}_{3} \mathrm{~N}_{4}$, respectively (Figure $4 \mathrm{~B}$ ). The shift in onset potential of $30 \mathrm{mV}$ for $\mathrm{CeO}_{2} / \mathrm{g}-\mathrm{C}_{3} \mathrm{~N}_{4}$ as compared to $\mathrm{CeO}_{2}$ indicates a synergetic interaction between $\mathrm{CeO}_{2}$ and $g-\mathrm{C}_{3} \mathrm{~N}_{4}$ in 

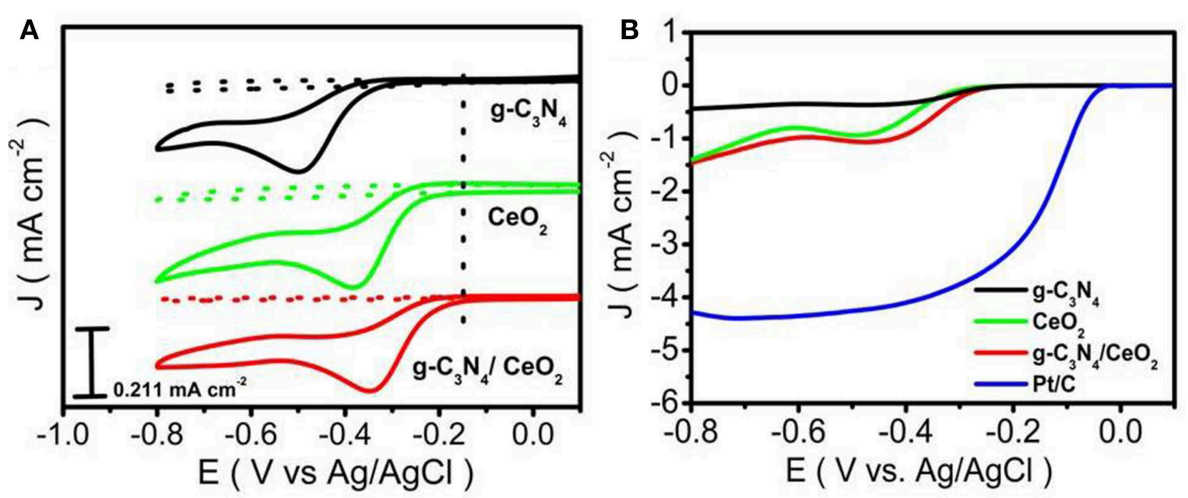

FIGURE 4 | (A) CV study of $\mathrm{g}-\mathrm{C}_{3} \mathrm{~N}_{4}, \mathrm{CeO}_{2}, \mathrm{CeO}_{2} / \mathrm{g}-\mathrm{C}_{3} \mathrm{~N}_{4}$, (B) LSV study of g- $\mathrm{C}_{3} \mathrm{~N}_{4}, \mathrm{CeO}_{2}, \mathrm{CeO}_{2} / \mathrm{g}-\mathrm{C}_{3} \mathrm{~N}_{4}$ and Pt/C at 1,600 rpm.
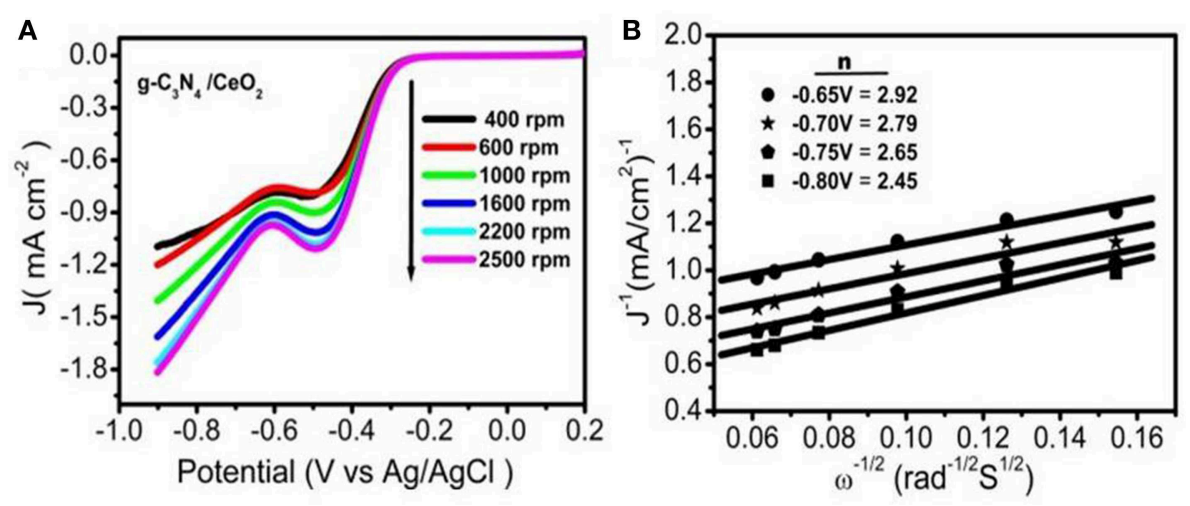

FIGURE 5 | (A) RDE of $\mathrm{CeO}_{2} / \mathrm{g}-\mathrm{C}_{3} \mathrm{~N}_{4}$ at various rotation rates, (B) K-L plot of $\mathrm{CeO}_{2} / \mathrm{g}-\mathrm{C}_{3} \mathrm{~N}_{4}$ at different potentials.

the composite which facilitates ORR, but the constancy in the current value of $\mathrm{CeO}_{2} / g-\mathrm{C}_{3} \mathrm{~N}_{4}$ composite with $\mathrm{CeO}_{2}$ indicates a slow ORR rate. A positive shift of onset potential $(100 \mathrm{mV})$ between $\mathrm{CeO}_{2} / g-\mathrm{C}_{3} \mathrm{~N}_{4}\left(\mathrm{E}_{\text {onset }}=-0.2 \mathrm{~V}\right.$ vs. $\left.\mathrm{Ag} / \mathrm{AgCl}\right)$ and $\mathrm{g}$ $\mathrm{C}_{3} \mathrm{~N}_{4}\left(\mathrm{E}_{\text {onset }}=-0.3 \mathrm{~V}\right.$ vs. $\left.\mathrm{Ag} / \mathrm{AgCl}\right)$ suggests a strong interaction between $\mathrm{CeO}_{2}$ and $\mathrm{g}-\mathrm{C}_{3} \mathrm{~N}_{4}$. We observed a small improvement in the $\mathrm{E}_{1 / 2}$ for $\mathrm{CeO}_{2} / \mathrm{g}-\mathrm{C}_{3} \mathrm{~N}_{4}$ composite $\left(\mathrm{E}_{1 / 2}\right.$ is $\left.-0.383 \mathrm{~V}\right)$ as compared to their individual counterparts $\left(\mathrm{E}_{1 / 2}\right.$ is $-0.383 \mathrm{~V}$ and $-0.388 \mathrm{~V}$ for bare $\mathrm{CeO}_{2}$ and $\mathrm{g}-\mathrm{C}_{3} \mathrm{~N}_{4}$, respectively) (Ferrero et al., 2016). LSVs of $\mathrm{CeO}_{2} / g-\mathrm{C}_{3} \mathrm{~N}_{4}$ at different rotation speeds from 400 to 2,500 rpm were carried out with Rotating Disk Electrode (RDE) to study electron transfer kinetics during ORR process (Figure 5A). It is observed that with an increase in rotation rate the diffusion rate of oxygen molecules also increases, which leads to a gradual increase in current density value. KouteckyLevich (K-L) plots were plotted (Figure 5B) in order to gain better insight into the electron transfer process during ORR. The Koutecky-Levich (K-L) equation is given as follows:

$$
\begin{array}{r}
1 / \mathrm{J}=1 / \mathrm{J}_{\mathrm{L}}+1 / \mathrm{J}_{\mathrm{K}}=(1 / \mathrm{B}) \omega^{-1 / 2}+1 / \mathrm{J}_{\mathrm{K}} \\
\mathrm{B}=0.62 \mathrm{nFC}_{0}\left(\mathrm{D}_{0}\right)^{2 / 3} v^{1 / 6}
\end{array}
$$

Here $\mathrm{J}$ is the measured current density, $\mathrm{J}_{\mathrm{L}}$ and $\mathrm{J}_{\mathrm{K}}$ are the diffusion and kinetic current densities, respectively, $\mathrm{n}$ is the transferred electron number per $\mathrm{O}_{2}$ molecule, $\omega$ is the angular velocity, $\mathrm{F}$ is the Faraday constant $\left(\mathrm{F}=96,485 \mathrm{C} \mathrm{mol}^{-1}\right), \mathrm{D}_{0}$ is the $\mathrm{O}_{2}$ diffusion coefficient $\left(1.9 \times 10^{-5} \mathrm{~cm}^{2} \mathrm{~s}^{-1}\right), \mathrm{C}_{0}$ is the bulk concentration of $\mathrm{O}_{2}\left(1.2 \times 10^{-3} \mathrm{~mol} \mathrm{~L}^{-1}\right)$, $v$ is the kinematic viscosity of the electrolyte $\left(0.01 \mathrm{~m}^{2} \mathrm{~s}^{-1}\right)$ (Soren et al., 2016). At various electrode potentials $\mathrm{J}^{-1}$ vs. $\omega^{-1 / 2}$ graphs were plotted for $\mathrm{CeO}_{2} / g-\mathrm{C}_{3} \mathrm{~N}_{4}$ (Figure 5B). The number of electrons transferred per $\mathrm{O}_{2}$ molecule ( $\mathrm{n}$ ) was calculated from the slopes of the best fit lines (Soren et al., 2016). The $n$ value for the $\mathrm{CeO}_{2} / g-\mathrm{C}_{3} \mathrm{~N}_{4}$ nanocomposite was calculated around 3 , which suggests the ORR kinetics proceeds through the 2-electron pathway.

To gain more information on the ORR mechanism, the electron transfer number ' $n$ ' and the rate of peroxide formation can be determined from the RRDE analysis (Ge et al., 2015). In RRDE, the ORR takes place at the GC disk (where the different catalysts were deposited) and the concentric $\mathrm{Pt}$ ring detects the peroxide production. Figure 6 shows the disk and ring currents for the $\mathrm{CeO}_{2}$ and $\mathrm{CeO}_{2} / g-\mathrm{C}_{3} \mathrm{~N}_{4}$ systems. Both catalysts generate ring current at the onset potential for the ORR. All three electrodes display large disk currents with relatively low ring current. Here, $\mathrm{n}$ is the 
number of electrons transferred, $\mathrm{I}_{\mathrm{D}}$ is the current measured at the GC disk, and $I_{R}$ is the current measured at the $\mathrm{Pt}$ ring obtained through RRDE (Qiao et al., 2016). The value of " $N$ " is 0.25 , denoting the collection efficiency which is a design parameter provided by the RRDE manufacturer. The following two equations are used to determine electron transfer number and amount of peroxide produced during ORR (Ge et al., 2015).

$$
\begin{aligned}
\mathrm{n} & =\frac{4 \mathrm{I}_{\mathrm{D}}}{\mathrm{I}_{\mathrm{D}}+\left(\mathrm{I}_{\mathrm{R}} / \mathrm{N}\right)} \\
\% \mathrm{HO}_{2}^{-} & =\frac{200\left(\mathrm{I}_{\mathrm{R}} / \mathrm{N}\right)}{\mathrm{I}_{\mathrm{D}}+\left(\mathrm{I}_{\mathrm{R}} / \mathrm{N}\right)}
\end{aligned}
$$

At lower over potential regions $(-0.4 \mathrm{~V}$ vs. $\mathrm{Ag} / \mathrm{AgCl})$, the average value of " $n$ " for $\mathrm{CeO}_{2}, \mathrm{CeO}_{2} / \mathrm{g}-\mathrm{C}_{3} \mathrm{~N}_{4}$ were $2.71,3.2$, respectively. The peroxide formation follows the reverse trend $\left(\mathrm{CeO}_{2}>\right.$ $\left.\mathrm{CeO}_{2} / g-\mathrm{C}_{3} \mathrm{~N}_{4}\right)$. At higher over potential regions $(-0.6 \mathrm{~V}$ vs. $\mathrm{Ag} / \mathrm{AgCl}$ ) the " $\mathrm{n}$ " of $\mathrm{CeO}_{2}$ and $\mathrm{CeO}_{2} / g-\mathrm{C}_{3} \mathrm{~N}_{4}$ remains constant, i.e., 2.57 and 3.2 respectively (Figure $7 \mathrm{~A}$ ). This indicates at the quasi-4-electron process followed $\mathrm{CeO}_{2} / \mathrm{g}-\mathrm{C}_{3} \mathrm{~N}_{4}$. The peroxide

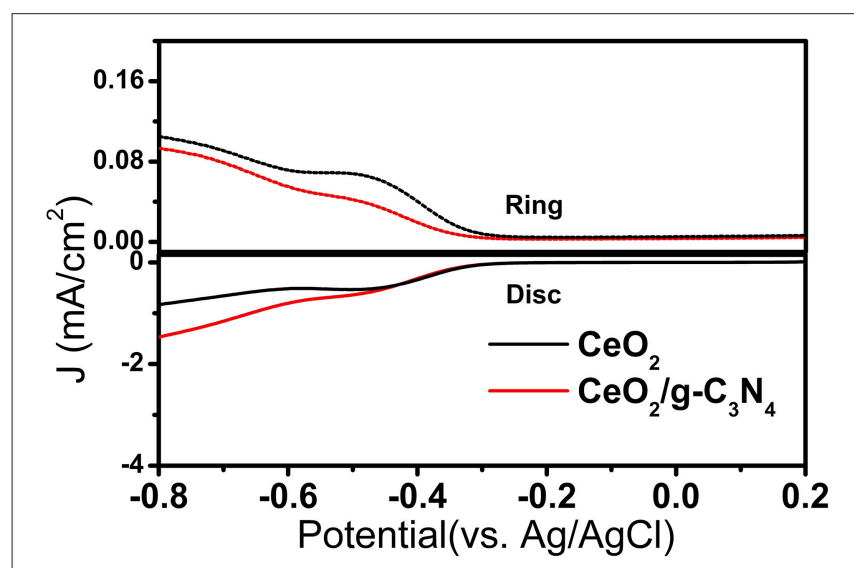

FIGURE 6 | RRDE Comparison of $\mathrm{CeO}_{2}$ and $\mathrm{CeO}_{2} / \mathrm{g}-\mathrm{C}_{3} \mathrm{~N}_{4}$ systems. formation follows the reverse trend $\left(\mathrm{CeO}_{2}>\mathrm{CeO}_{2} / g-\mathrm{C}_{3} \mathrm{~N}_{4}\right)$ at higher over potential regions (Figure 7B).

An enhancement of reaction kinetics toward the 4-electron ORR pathway is clearly observed from $\mathrm{CeO}_{2}$ to $\mathrm{CeO}_{2} / \mathrm{g}-\mathrm{C}_{3} \mathrm{~N}_{4}$. The ORR activity can be ascribed to the oxygen vacancies in the $\mathrm{CeO}_{2}$ lattice, which originated from the mixed valence states. The defects can be easily healed by oxygen adsorption when exposed to oxygen environment (Soren et al., 2016). The improved ORR activity of $\mathrm{CeO}_{2} / \mathrm{gC}_{3} \mathrm{~N}_{4}$ can be explained by considering the synergistic effect between $\mathrm{CeO}_{2}$ and carbon network containing different types of nitrogen (Pyridinc, pyrolic, and graphitic). Ruoff's group in their recent publication has confirmed the effect of nitrogen doping on the ORR activity (Lai et al., 2012). They have concluded that the catalytic activity is dependent on the nature and amount of nitrogen present in the matrix. It has been established that presence of graphitic nitrogen increases the limiting current whereas the pyridinic nitrogen alters the onset potential of ORR (Soren et al., 2016). $\mathrm{Li}$ et al. have shown that the direct reduction pathway for ORR is favored by the presence of pyridinic nitrogen (Li et al., 2013). Bag et al. also confirmed the vital role of pyridinic nitrogen in the enhancement of ORR activity (Bag et al., 2014). In this paper the XPS analysis reveals that $\mathrm{CeO}_{2} / g-\mathrm{C}_{3} \mathrm{~N}_{4}$ has $50.6 \%$ pyridinic nitrogen. This explains the shift in onset potential while going from $\mathrm{CeO}_{2}$ to $\mathrm{CeO}_{2} / \mathrm{gC}_{3} \mathrm{~N}_{4}$ composite (as discussed in Figure 4B)

Stability of electrocatalysts is another key parameter in the evaluation of their catalytic performance. The catalytic stability of $\mathrm{CeO}_{2} / \mathrm{g}-\mathrm{C}_{3} \mathrm{~N}_{4}$ along with commercial $\mathrm{Pt} / \mathrm{C}$ and bare $\mathrm{CeO}_{2}$ were measured and compared by the Chronoamperometric response method at $-0.35 \mathrm{~V}$ vs. $\mathrm{Ag} / \mathrm{AgCl}$ in $0.1 \mathrm{M} \mathrm{KOH}$ solution for $12,500 \mathrm{~s}$ at $1,000 \mathrm{rpm}$, and the results are shown in Figure 8 (Soren et al., 2016). As expected, $\mathrm{CeO}_{2} / \mathrm{g}-\mathrm{C}_{3} \mathrm{~N}_{4}$ exhibited better stability as compared to both $\mathrm{Pt} / \mathrm{C}$ as well as bare $\mathrm{CeO}_{2}$. Moreover, after $12,500 \mathrm{~s}$, relative current value for bare $\mathrm{CeO}_{2}$ and $\mathrm{Pt} / \mathrm{C}$ decreased by 53 and $40 \%$ respectively, while in case of $\mathrm{CeO}_{2} / \mathrm{g}-\mathrm{C}_{3} \mathrm{~N}_{4}$ composite a $24 \%$ decrease in the relative current was observed.

Methanol poisoning of the cathode impacts the ORR process. As a result, it is very much essential to address another important
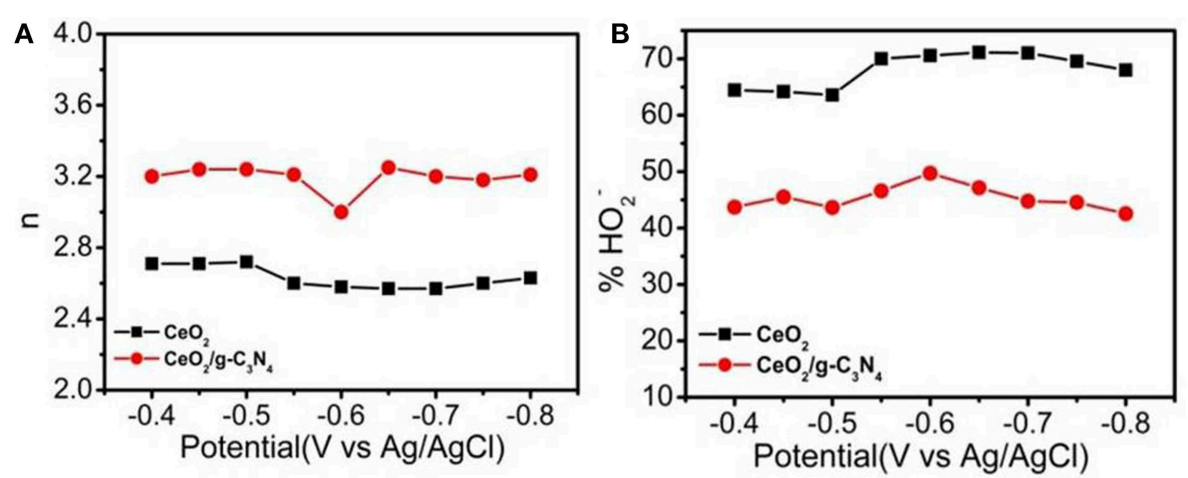

FIGURE 7 | (A) Electron transfer number, (B) \% of $\mathrm{HO}_{2}^{-}$formation of $\mathrm{CeO}_{2}$ and $\mathrm{CeO}_{2} / g-\mathrm{C}_{3} \mathrm{~N}_{4}$. 


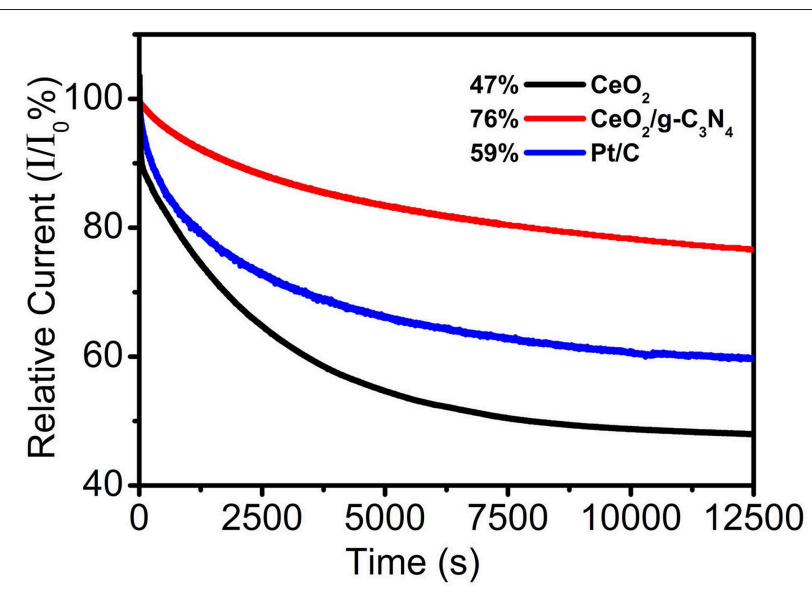

FIGURE 8 | (Current-time) chronoamperometric responses for $\mathrm{ORR}$ on $\mathrm{CeO}_{2}$, $\mathrm{CeO}_{2} / \mathrm{g}-\mathrm{C}_{3} \mathrm{~N}_{4}$ and commercial $\mathrm{Pt} / \mathrm{C}$ at $-0.35 \mathrm{~V}$ at a rotational rate of $1,000 \mathrm{rpm}$.

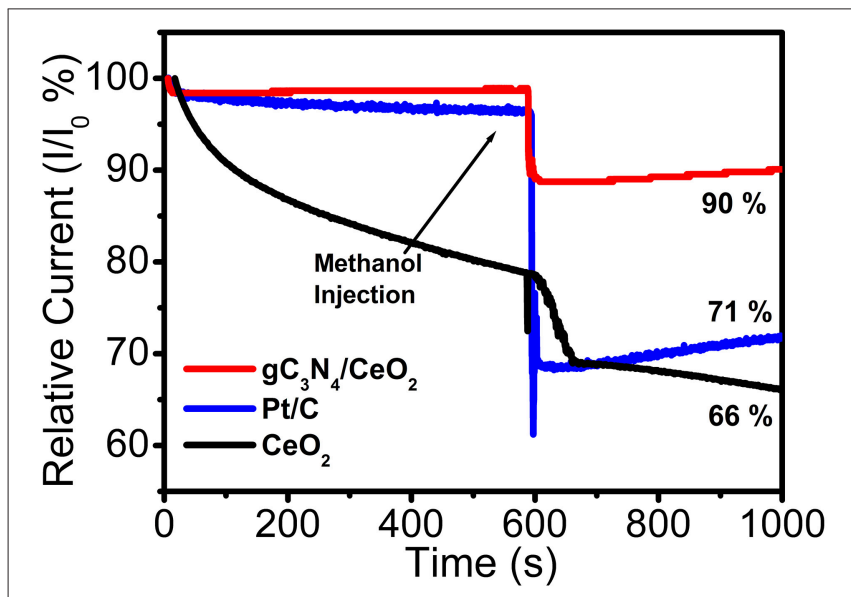

FIGURE 9 | Methanol tolerance test of $\mathrm{CeO}_{2}, \mathrm{CeO}_{2} / \mathrm{g}-\mathrm{C}_{3} \mathrm{~N}_{4}$, and commercial $\mathrm{Pt} / \mathrm{C}$.

factor of ORR catalysis-i.e., methanol tolerant capability (Bag et al., 2014). For methanol tolerance, test chronoamperometric measurements were performed at $-0.35 \mathrm{~V}$ vs. $\mathrm{Ag} / \mathrm{AgCl}$ at 1,000 rpm in $\mathrm{O}_{2}$ saturated $0.1 \mathrm{M} \mathrm{KOH}$ solution to investigate the methanol crossover effect of $\mathrm{CeO}_{2}, \mathrm{CeO}_{2} / \mathrm{g}-\mathrm{C}_{3} \mathrm{~N}_{4}$ composite as well as of commercial Pt/C. A total of $25 \mathrm{~mL}$ of (10 wt\%) $3 \mathrm{M}$ methanol was injected at $600 \mathrm{~s}$. It was observed that there was a $34 \%$ and $29 \%$ decrease in relative current for $\mathrm{CeO}_{2}, \mathrm{Pt} / \mathrm{C}$, respectively, whereas only a $10 \%$ decrease in relative current was observed for the $\mathrm{CeO}_{2} / g-\mathrm{C}_{3} \mathrm{~N}_{4}$ composite system (Figure 9). This result demonstrates the better methanol tolerance ability of $\mathrm{CeO}_{2} / \mathrm{g}-\mathrm{C}_{3} \mathrm{~N}_{4}$ as compared to $\mathrm{Pt} / \mathrm{C}$.

\section{Impedance Measurement}

Electrochemical impedance spectroscopy (EIS) is another potent technique to describe the electrocatalyst kinetics and interface properties in ORR (Perini et al., 2015). EIS analysis

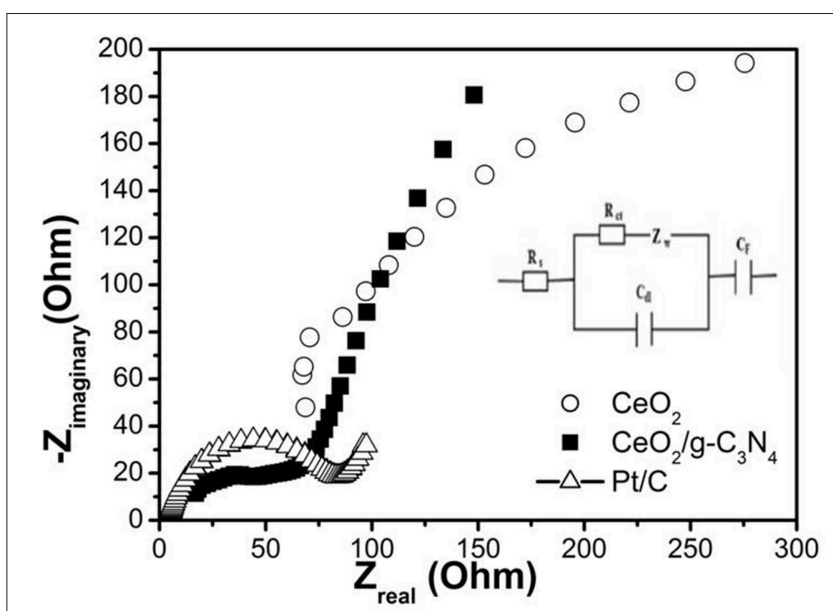

FIGURE 10 | Nyquist plot of as prepared electrocatalyst at $-0.21 \mathrm{~V}$ vs. $\mathrm{Ag} / \mathrm{AgCl}$ measured in $0.1 \mathrm{M} \mathrm{KOH}$ solution. Inserted: A simplified equivalent circuit.

through Nyquist plots is generally used to examine interfacial charge transport behavior of the electrode-electrolyte interface. The Nyquist plots demonstrate variation of impedance with frequency reflected as imaginary component vs. real component of impedance. Figure 10 shows the Nyquist plots over the frequency range $100-1 \mathrm{MHz}$ for the $\mathrm{CeO}_{2} / \mathrm{g}-\mathrm{C}_{3} \mathrm{~N}_{4}$ modified electrode in $0.1 \mathrm{M} \mathrm{KOH}$ solution with an $\mathrm{AC}$ amplitude of $0.1 \mathrm{~V}$ at an initial potential of $-0.210 \mathrm{~V}$. The Nyquist plot is represented at high frequency by a semicircular arc and at low frequency the plot is represented by a straight line. In this plot, the charge transfer resistance at the electrode-electrolyte interface is represented by the diameter of the semicircular arc whereas the diffusion nature of the electrolyte at the electrode surface is represented by a straight line (Parwaiz et al., 2017). The impedance data was fitted to an equivalent circuit (inset of Figure 10). The equivalent circuit consists of charge transfer resistance $\left(R_{c t}\right)$, solution resistance $\left(R_{s}\right)$, pseudocapacitance $\left(C_{F}\right)$, Warburg impedance $\left(\mathrm{Z}_{\mathrm{w}}\right)$, and double layer capacitance $\left(\mathrm{C}_{\mathrm{dl}}\right)$ (Tan and Ren, 2016). The semicircle intercepting the real axis is a combination of both charge transfer resistance $R_{c t}$ (Guan et al., 2018) and ionic resistance of electrolyte $R_{s}$ (Maheswari and Muralidharan, 2016). $R_{s}$ consists of bulk electrolyte solution resistance and electron transfer resistance whereas $R_{c t}$ can be ascribed to change transfer resistance at the electrode-electrolyte boundary (Maheswari and Muralidharan, 2015).

The calculated $\mathrm{R}_{\mathrm{s}}$ for the $\mathrm{CeO}_{2} / \mathrm{g}-\mathrm{C}_{3} \mathrm{~N}_{4}$ composite is $36.5 \Omega$. The value of $R_{S}$ of the electrodes can be attributed to the dissimilar conductivities and morphologies of the materials in their construction. A faster electron-transfer rate can be designated by a smaller $\mathrm{R}_{\mathrm{ct}}$ ( $\mathrm{Wu} \mathrm{Q}$. et al., 2017). Based on the observations, the diameter of the semicircle and the calculated $\mathrm{R}_{\mathrm{ct}}$ of the $\mathrm{CeO}_{2} / \mathrm{g}-\mathrm{C}_{3} \mathrm{~N}_{4}$ is $150 \Omega$ whereas the $\mathrm{R}_{\mathrm{ct}}$ for $\mathrm{CeO}_{2}$ and $\mathrm{Pt} / \mathrm{C}$ was found to be 534.4 and $77.3 \Omega$, respectively. The lower $\mathrm{R}_{\mathrm{ct}}$ value of $\mathrm{CeO}_{2} / g-\mathrm{C}_{3} \mathrm{~N}_{4}$ can be assigned to active electron transfer kinetics which in turn favor ORR catalytic activity. 


\section{CONCLUSION}

In accordance with the study report, $\mathrm{CeO}_{2} / g-\mathrm{C}_{3} \mathrm{~N}_{4}$ was successfully synthesized by a facile microwave mediated polyol route. The synergic effect of $\mathrm{CeO}_{2}$ after interacting $\mathrm{g}-\mathrm{C}_{3} \mathrm{~N}_{4}$ leads to the enhancement of ORR activity of the $\mathrm{CeO}_{2} / \mathrm{g}$ $\mathrm{C}_{3} \mathrm{~N}_{4}$ modified system as compared to bare $\mathrm{CeO}_{2}$. The XPS and ORR kinetics study results reveal that $\mathrm{CeO}_{2} / g-\mathrm{C}_{3} \mathrm{~N}_{4}$ with high levels of pyridinic nitrogen performs better ORR catalytic activity, implying a vital role of pyridinic nitrogen as promoter of ORR. The composites have shown excellent ORR stability and methanol tolerance behavior than commercial $\mathrm{Pt} / \mathrm{C}$. The low cost and facile synthesis procedure predict the future utility of the $\mathrm{CeO}_{2} / g-\mathrm{C}_{3} \mathrm{~N}_{4}$ composite in energy conversion system.

\section{REFERENCES}

Bag, S., Roy, K., Gopinath, C. S., and Raj, C. R. (2014). Facile singlestep synthesis of nitrogen-doped reduced graphene oxide- $\mathrm{Mn}_{3} \mathrm{O}_{4}$ hybrid functional material for the electrocatalytic reduction of oxygen. ACS Appl. Mater. Interf. 6, 2692-2699. doi: 10.1021/am4 $05213 z$

Bashyam, R., and Zelenay, P. (2006). A class of non-precious metal composite catalysts for fuel cells. Nat. Lett. 443, 63-66. doi: 10.1038/nature 05118

Behnam, S. (2017). Bio-inspired iron metal-carbon black based nanoelectrocatalyst for the oxygen reduction reaction. Pigment Resin Technol. 46, 267-275. doi: 10.1108/PRT-07-2016-0081

Benson, J., Xu, Q., Wang, P., Shen, Y., Sun, L., Wang, T., et al. (2014). Tuning the catalytic activity of graphene nanosheets for oxygen reduction reaction via size and thickness reduction. ACS Appl. Mater. Interf. 6 19726-19736. doi: 10.1021/am50 48202

Bojdys, M. J., Muller, J. O., Antonietti, M., and Thomas, A. (2008). Ionothermal synthesis of crystalline, condensed, graphitic carbon nitride. Chem. Eur. J. 14, 8177-8182. doi: 10.1002/chem.200800190

Cheng, F., and Chen, J. (2012). Metal-air batteries: from oxygen reduction electrochemistry to cathode catalysts. Chem. Soc. Rev. 41, 2172-2192. doi: $10.1039 / \mathrm{clcs} 15228 \mathrm{a}$

Cheng, F., Shen, J., Ji, W., Tao, Z., and Chen, J. (2009). Selective synthesis of manganese oxide nanostructures for electrocatalytic oxygen reduction. ACS Appl. Mater. Interf. 2, 460-466. doi: 10.1021/am800131v

Ferrero, G. A., Antonio, B. F., Marta, S., and Maria-Magdalena, T. (2016). Efficient metal-free $\mathrm{N}$-doped mesoporous carbon catalysts for ORR by a template-free approach. Carbon 106, 179-187. doi: 10.1016/j.carbon.2016. 04.080

Ge, X., Sumboja, A., Wu, D., Wuu, T., An, T., Li, B., et al. (2015). Oxygen reduction in alkaline media: from mechanisms to recent advances of catalysts. ACS Catal. 5, 4643-4667. doi: 10.1021/acscatal.5b 00524

Geng, D., Chen, Y., Li, Y., Li, R., Sun, X., Ye, S., et al. (2011). High oxygenreduction activity and durability of nitrogen-doped grapheme. Energ. Environ. Sci. 4, 11760-11764. doi: 10.1039/c0ee00326c

Guan, W., Sun, G., Yin, L., Zhang, Z., and Tian, S. (2018). $\mathrm{Ti}_{4} \mathrm{O}_{7} / g-\mathrm{C}_{3} \mathrm{~N}_{4}$ Visible light photocatalytic performance on hypophosphite oxidation: effect of annealing temperature. Front. Chem. 6, 37-47. doi: 10.3389/fchem.2018.00037

Guo, J. S., and Sun, H. S. (2012). FePt nanoparticles assembled on graphene as enhanced catalyst for oxygen reduction reaction. J. Am. Chem. Soc. 134, 2492-2495. doi: 10.1021/ja2104334

Guo, J. S., Zhang, S., Wu, H. L., and Sun, H. S. (2012). Co/CoO nanoparticles assembled on graphene for electrochemical reduction of oxygen. Angew. Chem. Int. Ed. 51, 11770-11773. doi: 10.1002/anie.201206152

\section{DATA AVAILABILITY}

The datasets generated for this study are available on request to the corresponding author.

\section{AUTHOR CONTRIBUTIONS}

The project is designed by PP. Scientific contributions in term of knowledge and discussion given by KV. SS and IH did the experimental work. DA and AD did the XPS analysis.

\section{ACKNOWLEDGMENTS}

This work was funded and supported by DST SERB, India (Grant no. EMR/2016/006050).

Ikeda, T., Boero, M., Huang, F. S., Terakura, K., Oshima, M., and Ozaki, I. J. (2008) Carbon alloy catalysts: active sites for oxygen reduction reaction. J. Phys. Chem. C 112, 14706-14709. doi: 10.1021/jp806084d

Jaouen, F., Proietti, E., Lefevre, M., Chenitz, R., Dodelet, J., Wu, P. G., et al. (2011). Recent advances in non-precious metal catalysis for oxygen-reduction reaction in polymer electrolyte fuel cells. Ener. Environ. Sci. 4, 114-130. doi: 10.1039/C0EE00011F

Jiao, Y., Zheng, Y., Jaroniec, M., and Qiao, S. Z. (2014). Origin of the electrocatalytic oxygen reduction activity of graphene-based catalysts: a roadmap to achieve the best performance. J. Am. Chem. Soc. 136, 4394-4403. doi: 10.1021/ja500432h

Kim, H., Lee, K., Woo, I. S., and Jung, Y. (2011). On the mechanism of enhanced oxygen reduction reaction in nitrogen-doped graphene nanoribbon. Phys. Chem. 13, 17505-17510. doi: 10.1039/c1cp21665a

Kim, J., Lee, Y., and Sun, S. (2010). Structurally ordered Fe Pt nanoparticles and their enhanced catalysis for oxygen reduction reaction. J. Am. Chem. Soc. 132, 4996-4997. doi: 10.1021/ja1009629

Lai, L., Potts, R. J., Zhan, D., Wang, L., Poh, K. C., Tang, C., et al. (2012). Exploration of the active center structure of nitrogen-doped graphene-based catalysts for oxygen reduction reaction. Energy Environ. Sci. 5, 7936-7942. doi: $10.1039 /$ c2ee21802j

Li, H., Kang, W., Wang, L., Yue, Q., Xu, S., Wang, H., et al. (2013). Synthesis of three-dimensional flowerlike nitrogen-doped carbons by a copyrolysis route and the effect of nitrogen species on the electrocatalytic activity in oxygen reduction reaction. Carbon 54, 249-257. doi: 10.1016/j.carbon.2012. 11.036

Li, L., Xianghong, F., Yao, N., Siguo, C., Feng, S., Kun, X., et al. (2015). Insight into the effect of oxygen vacancy concentration on the catalytic performance of $\mathrm{MnO}_{2}$. ACS Catal. 5 4825-4832. doi: 10.1021/acscatal.5b 00320

Li, Y., Zhao, Y., Cheng, H., Hu, Y., Shi, G., Dai, L., et al. (2011). Nitrogen-doped graphene quantum dots with oxygen-rich functional groups. J. Am. Chem. Soc. 134, 15-18. doi: 10.1021/ja206030c

Liang, Y., Li, Y., Wang, H., Zhou, G. J., Wang, and, J., and Dai, H. (2011). $\mathrm{Co}_{3} \mathrm{O}_{4}$ nanocrystals on graphene as a synergistic catalyst for oxygen reduction reaction. J. Nat. Mater. 10, 780-786. doi: 10.1038/nmat3087

Liang, Y., Wang, H., Zhou, J., Li, Y., Wang, J., Regier, T., et al. (2012). Covalent hybrid of spinel manganese-cobalt oxide and graphene as advanced oxygen reduction electrocatalysts. J. Am. Chem. Soc. 134, 3517-3523. doi: 10.1021/ja21 0924t

Liu, Q., and Zhang, J. (2013). Graphene supported Co-g- $\mathrm{C}_{3} \mathrm{~N}_{4}$ as a novel metalmacrocyclic electrocatalyst for the oxygen reduction reaction in fuel cells. Langmuir 29, 3821-3828. doi: 10.1021/la400003h

Liu, R., Wu, D., Feng, X., and Mullen, K. (2010). Nitrogen-doped ordered mesoporous graphitic arrays with high electrocatalytic activity for oxygen reduction. Angew. Chem. Int. Ed. 122, 2619-2623. doi: 10.1002/ange.2009 07289 
Maheswari, N., and Muralidharan, G. (2015). Supercapacitor behaviour of cerium oxide nanoparticles in nuteral aqueous electrolutes. Energy Fuels 29, 8246-8253. doi: 10.1021/acs.energyfuels.5b02144

Maheswari, N., and Muralidharan, G. (2016). Hexagonal $\mathrm{CeO}_{2}$ nanostructures: an efficient electrode material for supercapacitors. Dalton Trans. 45, 14352-14362. doi: 10.1039/C6DT03032G

Niwa, H., Horiba, K., Harada, Y., Oshima, M., Ikeda, T., Terakura, K., et al. (2009). X-ray absorption analysis of nitrogen contribution to oxygen reduction reaction in carbon alloy cathode catalysts for polymer electrolyte fuel cells. J. Power Sources 187, 93-97. doi: 10.1016/j.jpowsour.2008. 10.064

Paraknowitsch, P. J., and Thomas, A. (2013). Doping carbons beyond nitrogen: an overview on advanced heteroatom doped carbons with boron, sulphur and phosphorus for energy applications. Energy. Environ. Sci. 6, 2839-2855. doi: $10.1039 / \mathrm{c} 3 e e 41444 \mathrm{~b}$

Parvez, K., Yang, B. S., Hernandez, Y., Winter, A., Turchanin, A., Feng, L. X., et al. (2012). Nitrogen-doped graphene and its iron-based composite as efficient electrocatalysts for oxygen reduction reaction. ACS Nano 6, 9541-9550. doi: $10.1021 / \mathrm{nn} 302674 \mathrm{k}$

Parwaiz, S., Bhunia, K., Das, A. K., Khan, M. M., and Pradhan, D. (2017). Cobalt-doped ceria/reduced graphene oxide nanocomposite as an efficient oxygen reduction reaction catalyst and supercapacitor material. J. Phys. Chem. C. 121, 20165-20176. doi: 10.1021/acs.jpcc.7 b06846

Peng, Z. M., and Yang, H. (2009). Synthesis and oxygen reduction electrocatalytic property of Pt-on-Pd bimetallic heteronanostructures. J. Am. Chem. Soc. 131, 7542-7543. doi: $10.1021 / \mathrm{ja} 902256 \mathrm{a}$

Perini, L., Durante, C., Favaro, M., Perazzolo, V., Agnoli, S., Granozzi, G., et al. (2015). Metal-support interaction in platinum and palladium nanoparticles loaded on nitrogen doped mesoporous carbon for oxygen reduction reaction. ACS Appl. Mater. Interf. 7, 1170-1179. doi: 10.1021/am50 $6916 y$

Qiao, X., Shijun, L., Guanghua, W., Ruiping, Z., Huiyu, S., and Xiuhua, L. (2016). Simultaneous doping of nitrogen and fluorine into reduced graphene oxide: a highly active metal-free electrocatalyst for oxygen reduction, Carbon, 2016.Carbon. 99, 272-279. doi: 10.1016/j.carbon.2015.12.034

Qu, L., Liu, Y., Baek, B. J., and Dai, L. (2010). Nitrogen-doped graphene as efficient metal-free electrocatalyst for oxygen reduction in fuel cells. ACS Nano 4, 1321-1326. doi: 10.1021/nn901850u

Rao, V. C., Cabrera, R. C., and Ishikawa, Y. (2010). In Search of the active site in nitrogen-doped carbon nanotube electrodes for the oxygen reduction reaction. J. Phys. Chem. Lett. 1, 2622-2627. doi: 10.1021/jz100971v

Raymundo-Pinero, E., Cazorla-Amoros, D., Linares-Solano, A., Find, J., Wild, U., and Schlogl, R. (2002). Structural characterization of N-containing activated carbon fibers prepared from a low softening point petroleum pitch and a melamine resin. Carbon 40, 597-608. doi: 10.1016/S0008-6223(01)00155-5

Sharifi, T., Hu, G., Jia, X., and Wagberg, T. (2012). Formation of active sites for oxygen reduction reactions by transformation of nitrogen functionalities in nitrogen-doped carbon nanotubes. ACS Nano 6, 8904-8912. doi: $10.1021 / \mathrm{nn} 302906 \mathrm{r}$

Sheng, H. Z., Shao, L., Chen, J. J., Bao, W. J., Wang, B. F., and Xia, H. X. (2011). Catalyst-free synthesis of nitrogen-doped graphene via thermal annealing graphite oxide with melamine and its excellent electrocatalysis. ACS Nano 5, 4350-4358. doi: 10.1021/nn103584t

Soren, S., Bessoi, M., and Parhi, P. (2015). A rapid microwave initiated polyol synthesis of cerium oxide nanoparticle using different cerium precursors. Ceram. Int. 41, 8114-8118. doi: 10.1016/j.ceramint.2015.03.013

Soren, S., Mohapatra, B. D., Mishra, S., Debnath, A. K., Aswal, D. K., Varadwaj, K. S. K., et al. (2016). Nano ceria supported nitrogen doped graphene as a highly stable and methanol tolerant electrocatalyst for oxygen reduction. RSC Adv. 6, 77100-77104. doi: 10.1039/C6RA13218A

Sun, S., Xue, Y., Wang, Q., Li, S., Huang, H., Miao, H., et al. (2017). Electrocatalytic activity of silver decorated ceria microsphere for oxygen reduction reaction and its application in aluminium-air battery. Chem. Comm. 53, 7921-7924. doi: 10.1039/C7CC03691D

Tan, H., and Ren, Z. (2016). Facile Synthesis of $\mathrm{Co}_{3} \mathrm{O}_{4} /$ Nitrogen-doped graphene Composite with enhanced electrochemical performance. Mater. Sci. Forum 847, 14-21. doi: 10.4028/www.scientific.net/MSF.847.14
Thomas, A., Fischer, A., Goettmann, F., Antonietti, M., Müller, J. O., Schlögl, R., et al. (2008). Graphitic carbon nitride materials: variation of structure and morphology and their use as metal-free catalysts. J. Mater. Chem. 18, 4893-4908. doi: 10.1039/b800274f

Wang, H., Liang, Y., Li, G. Y., and Dai, J. H. (2011). $\mathrm{Co}_{1-\mathrm{x}}$ S-graphene Hybrid: a high-performance metal chalcogenide electrocatalyst for oxygen reduction. Angew. Chem. Int. Ed. 50, 10969-10972. doi: 10.1002/anie.201104004

Wang, N., Liu, J., Gu, W., Song, Y., and Wang, F. (2016). Toward synergy of carbon and $\mathrm{La}_{2} \mathrm{O}_{3}$ in their hybrid as efficient catalyst for oxygen reduction reaction. RSC Adv. 6, 77786-77795. doi: 10.1039/C6RA17104D

Wang, S., Zhang, L., Xia, Z., Roy, A., D. W., Chang, J. B., et al. (2012). $\mathrm{BCN}$ graphene as efficient metal-free electrocatalyst for the oxygen reduction reaction. Angew. Chem Int. Ed. 51, 4209-4212. doi: 10.1002/anie.201109257

Wang, W., Song, J., Kang, Y., Chai, D., Zhao, R., and Lei, Z. (2017). $\mathrm{Sm}_{2} \mathrm{O}_{3}$ embedded in nitrogen doped carbon with mosaic structure: an effective catalyst for oxygen reduction reaction. Energy 133,115-120. doi: 10.1016/j.energy.2017.05.095

Wang, X., Maeda, K., Thomas, A., Takanabe, K., Xin, G., Carlsson, J. M., et al. (2009). A metal-free polymeric photocatalyst for hydrogen production from water under visible light. Nat. Mater. 8, 76-80. doi: 10.1038/ nmat 2317

Wu, H. K., Zeng, Q., Zhang, B., Leng, X., Su, S. D., Gentle, R. I., et al. (2015). Structural origin of the activity in $\mathrm{Mn}_{3} \mathrm{O}_{4}$-graphene oxide hybrid electrocatalysts for the oxygen reduction reaction. Chem. Sus. Chem. 8, 3331-3339. doi: 10.1002/cssc.201500372

Wu, Q., Jiang, M., Zhang, X., Cai, J., and Lin, S. (2017). A novel octahedral $\mathrm{MnO} / \mathrm{RGO}$ composite prepared by thermal decomposition as a noble-metal free electrocatalyst for ORR. J. Mater. Sci. 52, 6656-6669. doi: 10.1007/s10853-017-0901-4

Wu, X., Zhu, C., Wang, L., Guo, S., Zhang, Y., Li, H., et al. (2017). Control strategy on two-/four-electron pathway of water splitting by multidoped carbon based catalysts. ACS Catal. 3, 1637-1645. doi: 10.1021/acscatal.6b 03244

Xing, T., Zheng, Y., Li, H. L., Cowie, C. C. B., Gunzelmann, D., Qiao, S. Z., et al. (2014). Observation of active sites for oxygen reduction reaction on nitrogendoped multilayer graphene. ACS Nano 8, 6856-6862. doi: 10.1021/nn5 $01506 \mathrm{p}$

Xu, M., Han, L., and Dong, S. (2013). Facile fabrication of highly efficient g- $\mathrm{C}_{3} \mathrm{~N}_{4} / \mathrm{Ag}_{2} \mathrm{O}$ heterostructured photocatalysts with enhanced visiblelight photocatalytic activity. ACS Appl. Mater. Interf. 5, 12533-12540. doi: $10.1021 / \mathrm{am} 4038307$

Yan, H., Chen, Y., and Xu, S. (2012). Synthesis of graphitic carbon nitride by directly heating sulfuric acid treated melamine for enhanced photocatalytic $\mathrm{H}_{2}$ production from water under visible light. Int. J. Hydrogen Energy 37, 125-133. doi: 10.1016/j.ijhydene.2011.09.072

Yan, S. C., Li, Z. S., and Zou, Z. G. (2009). Photodegradation performance of $\mathrm{g}_{-} \mathrm{C}_{3} \mathrm{~N}_{4}$ fabricated by directly heating melamine. Langmuir 25, 10397-10401. doi: 10.1021/la9 $00923 z$

Yang, Z., Yao, Z., Li, G., Fang, G., Nie, H., Liu, Z., et al. (2012). Sulfur-doped graphene as an efficient metal-free cathode catalyst for oxygen reduction. ACS Nano 6, 205-211. doi: 10.1021/nn20 $3393 d$

Zhang, C., Hao, R., Liao, H., and Hou, Y. (2013). Synthesis of aminofunctionalized graphene as metal-free catalyst and exploration of the roles of various nitrogen states in oxygen reduction reaction. Nano Energy 2, 88-97. doi: 10.1016/j.nanoen.2012.07.021

Zhang, J., and Song, C. (2008). Electrocatalytic oxygen reduction reaction, PEM fuel cell electrocatalysts and catalyst layers(springer) 2008, 189-134. doi: 10.1007/978-1-84800-936-3

Zhang, L., and Xia, Z. (2011). Mechanisms of oxygen reduction reaction on nitrogen-doped graphene for fuel cells. J. Phys. Chem. C 115, 11170-11176. doi: $10.1021 /$ jp201991j

Zhang, Y., Thomas, A., Antonietti, M., and Wang, X. C. (2008). Activation of carbon nitride solids by protonation: morphology changes, enhanced ionic conductivity, and photoconduction experiments. J. Am. Chem. Soc. 131, 50-51. doi: 10.1021/ja8 $08329 \mathrm{f}$ 
Zheng, B., Wang, J., Wang, B. F., and Xia, H. X. (2013). Synthesis of nitrogen doped graphene with high electrocatalytic activity toward oxygen reduction reaction. Electrochem. Commun. 28, 24-26. doi: 10.1016/j.elecom.2012.11.037

Zheng, Y., Jiao,Y., Zhu, Y., Cai, Q., Vasileff, A., Li, L. H., et al. (2017). Molecule-level g- $\mathrm{C}_{3} \mathrm{~N}_{4}$ coordinated transition metals as a new class of electrocatalysts for oxygen electrode reactions. J. Am. Chem. Soc. 139, 3336-3339. doi: 10.1021/jacs.6b13100

Zou, X., Su, J., Silva, R., Goswami, A., Sathe, B. R., and Asefa, T. (2013). Efficient oxygen evolution reaction catalyzed by low-density Ni-doped $\mathrm{Co}_{3} \mathrm{O}_{4}$ nanomaterials derived from metal-embedded graphitic $\mathrm{C}_{3} \mathrm{~N}_{4}$. Chem. Commun. 49, 7522-7524. doi: 10.1039/c3cc42891e
Conflict of Interest Statement: The authors declare that the research was conducted in the absence of any commercial or financial relationships that could be construed as a potential conflict of interest.

Copyright (๑) 2019 Soren, Hota, Debnath, Aswal, Varadwaj and Parhi. This is an open-access article distributed under the terms of the Creative Commons Attribution License (CC BY). The use, distribution or reproduction in other forums is permitted, provided the original author(s) and the copyright owner(s) are credited and that the original publication in this journal is cited, in accordance with accepted academic practice. No use, distribution or reproduction is permitted which does not comply with these terms. 